\title{
LECTIO DIVINA, MEDITATIO, ORATIO, CONTEMPLATIO AS BASIC CATEGORIES OF MEDIEVAL SPIRITUALITY
}

\author{
KIRILL V. KARPOV \\ Russian Academy of Sciences
}

\begin{abstract}
Mysticism is one of the most vague concepts in religious studies. In what follows I propose to boil down mysticism to spirituality and provide an analysis of lectio divina (a spiritual practice which originated in the Middle Ages and still exists). I will also show how we can understand spirituality and how people can produce 'spiritual knowledge'.
\end{abstract}

\section{INTRODUCTION}

The themes of medieval spirituality in general and medieval mysticism in particular have attracted scholars ever since that era. To review all the works from medieval and religious studies, which set the specifics of 'mysticism' of a particular author (or authors), trace the historical development of forms of medieval piety and mysticism, and analyze the conceptual design of mystical practices and offer their interpretation, is beyond the intellectual capabilities of one scholar. That is why I am not going to present a theory of medieval Western mysticism. Moreover, religious studies does not provide us with a clear, generally accepted definition of the terms 'mystical' or 'mysticism'. Indeed, it is highly unlikely that there would be such a definition, due to the methodological and philosophical differences of all who study mysticism, mystical experiences, and religions.

Here is a hermeneutical problem: I suppose a historian should get the definition of 'mystical' from the corresponding discipline, thereby the 'mysticism' of a particular author should be a subject of research. But how can the scholar of religion define 'mysticism' and 'mystical' without 
having received from the historian the data marked by this label? Therefore, in this paper I set a simpler problem: a study of the specifics of what is commonly named 'spiritual practice'. I raise the following question: how should we think about spirituality? This question has two meanings: on the one hand, it asks what 'spirituality' is, on the other - how people can produce 'spiritual knowledge'. The historical texts that I will present and analyze are written by Carthusians, or by authors close to them, and are usually considered to be works of mysticism, but not only mysticism, as they belong to the sphere of the 'human spirit' - including ethical, religious, and philosophical investigations.

\section{LECTIO DIVINA}

The practice of lectio divina is usually attributed to the following words of Cyprian of Carthage (d. 248) 1: 'You should apply yourself to prayer or to reading: at times you speak with God, at times He speaks with you.'2 This saying conveys the essence of lectio divina: 'an intimate dialogue with a living, present, divine interlocutor who will answer when the reader appeals to him.' ${ }^{3}$ The practice of lectio divina has its origins in the New Testament: 'In the beginning was the Word, and the Word was with God, and the Word was God' (John 1:1), 'And I say unto you, Ask, and it shall be given you; seek, and ye shall find; knock, and it shall be opened unto you' (Luke 11:9), 'For the word of God is living and powerful, and sharper than any two-edged sword' (Hebrews 4:12), 'All Scripture is given by inspiration of God, and is profitable for doctrine, for reproof, for correction, for instruction in righteousness' (2 Timothy $3: 16)$, 'So then faith cometh by hearing, and hearing by the word of God' (Romans 10:17). Divine reading is based on the notion of the inspiration of Scripture: we can start communication with God, which cannot be

${ }^{1}$ Duncan Robertson, Lectio Divina: The Medieval Experience of Reading (Collegeville, Minnesota: Liturgical Press, 2011), p. xi.

2 Sit tibi vel oratio assidua vel lectio: nunc cum Deo loquere, nunc Deus tecum. Cyprianus Carthaginensis, Epistola, I, 15 (PL 4, 221). Cf. Oras, loqueris ad Sponsum: legis, ille tibi loquitur (Hieronymus Stridonensis, Epistolae, XXII, 25 (PL 22, 411)); Illum alloquimur cum oramus, illum audimus cum divina legimus oracula (Ambrosius Mediolanensis, De officiis, I, 20, 88 (PL 16, 50)); Nam cum oramus, cum Deo ipsi loquimur; cum vero legimus, Deus nobiscum loquitur (Isidorus Hispalensis, Sententiae, III, 8, 2 (PL 83, 679)); Nam cum oramus, ipsi cum Deo loquimur: cum vero legimus, Deus nobiscum loquitur (Smaragdus S. Michaelis, Diadema monachorum. III (PL 102, 597)).

${ }^{3}$ Duncan Robertson, Lectio Divina, pp. xi-xii. 
mutual, only if Scripture was written by the inspiration of divine grace to his chosen people. Early theorists of lectio divina stressed: to achieve the state when the text will answer a reader's questions, reading should be performed regularly: 'As our mind is increasingly renewed by this study, the face of Scripture will also begin to be renewed, and the beauty of a more sacred understanding will somehow grow with the person making progress. ${ }^{3}$ In addition, lectio divina presupposes that a spiritual text has many meanings to which the reader is given access depending on her spiritual level: firstly, a reader understands the literal meaning, but as time passes and her spirituality grows she is able to understand the moral and anagogical meanings. The reading of Scripture and other spiritual, pious literature cannot be completed: in principle, it is an endless process.

The practice of reading described by Cassian in which the understanding of Scripture's meaning is constantly increasing requires a special place where there would be ideal conditions for its implementation. Beginning with the fifth century, lectio divina was primarily associated with the monastic life. The 'Rule of St. Benedict' schedules special times in the daily routine for reading and meditation. ${ }^{5}$ Similar conditions are found in other early rules. Scripture was usually read out loud, and this is important for two reasons. First, a monk in the era of St. Benedict had to read the Scriptures out loud for the first time for proper understanding of the text. Secondly, the practice of reading aloud was a kind of mnemonics - a monk had to recall certain scenes from Scripture at certain hours, and imagine those events. In this case mnemonics was the basis of meditation.

'In early monastic rules meditatio meant repetition, memorization, and recitation.' ${ }^{1}$ So initially the term did not refer to 'meditation' itself, but rather to the process of memorizing. Meditation is designed also to provide an easier, quicker reading, as opposed to reading text that a monk sees for the first time. Isidore of Seville writes: 'Reading needs the aid of memory, and even if memory is sluggish, it is sharpened by frequent meditatio, and recovered by assiduous reading." Thus, meditatio

${ }^{4}$ Crescente autem per hoc stadium innovatione mentis nostrae etiam scripturarum facies incipiet innovari, et sacratioris intelligentae pulchritude quodammodo cum proficiente proficient. Casssianus, Collationes, XIV, 11, 1.

${ }^{5}$ Benedictus de Nursia, Regula, 48 (PL 66, 703-4).

${ }^{6}$ Duncan Robertson, Lectio Divina, p. xiv.

${ }^{7}$ Isidorus Hispalensis, Sententiae, III, 14, 7-8 (PL 83, 689). 
is a continuation of lectio. Moreover, St. Benedict uses these terms interchangeably (meditare aut legere) ${ }^{8}$ indicating that they express two aspects of the same practice.

The fundamental assumption of the multiplicity of objective meanings of Scripture and therefore of many possible interpretations thereof stemmed from the commentary literature of late antiquity and persisted throughout the Middle Ages. Biblical exegesis and lectio divina developed in tandem. ${ }^{9}$ In addition, interpretation presupposes a dialogue with the real present or imaginary audience (for instance, Augustine's sermons on the psalms, in Gregory's Moralia on Job and his Homilies on Ezekiel, in Bernard of Clairvaux's Sermons on the Song of Songs.)

Beginning with the sixth century there appear thematically organized extractions from Scripture and patristic writings - florilegia - which were made to simplify and thematize the practice of divine reading and interpretation. Another example of the compilation of texts for reading is Benedict of Aniane's (c. 750-821) Concordia Regularum, the text which follows the Rule of Saint Benedict. Finally, we find compilations of texts for reading in prayer books, created for the laity from the eighth century, in which, again, passages from Scripture are combined with excerpts from the writings of the Church Fathers. The same practice we find in the Books of Hours from the fourteenth and fifteenth centuries, which are devotional books with weekly cycles of psalms, prayers, hymns, antiphons, and readings, which were changed with the liturgical season, and were supposed to be carried with their owner. These books were designed for both clergy and laity; in the latter case, they contained fewer extracts from texts.

John of Fécamp's (d. 1079) Confessio theologica marks a special point in the development of the compilation genre and in the understanding of meditatio. At the turn of the twelfth century, we note an increasing theoretical consciousness expressed in introductory statements and in instructions to real or ideal readers. This is especially clear in St. Anselm's warning that his Prayers and Meditations should be read not hurriedly or in turmoil, but quietly and thoughtfully. So that person is able to read as much as divine help allows. ${ }^{10}$ Hugh of Saint Victor in 'Didascalicon' formulates his main argument concerning exegesis in the context of and together with the practice of lectio divina. As regards the

\footnotetext{
${ }^{8}$ Benedictus de Nursia, Regula, 48 (PL 66, 215-930).

${ }^{9}$ Duncan Robertson, Lectio Divina, p. xv.

${ }^{10}$ Anselmus Cantuariensis, Meditationes et orations, prologus (PL 158, 709).
} 
practice of understanding, Hugo notes that it comes from reading, but is not connected with its rules. ${ }^{11}$ This kind of self-reflection gives impetus to further development of lectio divina.

\section{MEDITATIO}

While the understanding of lectio divina remained essentially the same throughout the ages (slow reading aloud or silently pieces from Scripture and (or) from writings of the Church Fathers), in contrast we find several possible interpretations of meditatio. They differ primarily in the recipient, who is offered one or another interpretation.

Pseudo-Bonaventure (Iohannes de Caulibus, XIV c.), in the Meditations on the Life of Christ (Meditationes Vitae Christi), offers a meditation practice for illiterate Christians. The main point of his exercise can be described as 'empathy' (Einfühlung) - constant repetition of Biblical situations and imagination of their own participation in these events. So that meditatio involves all five imaginary senses, corresponding to the real ones:

I will talk about events as they might occur in order to strengthen experience; I will introduce to you some imaginary pictures, so that the soul can perceive them by different senses: it does not matter, whether it was so, it is enough that it is probable. ${ }^{12}$

All these senses have to act simultaneously in order to create the effect of personal presence:

And you, if you want the meditation to be fruitful, imagine that you are present at those events about which the story is told, and your ears hear the words spoken by the Lord Jesus, your eyes see what He is doing. ${ }^{13}$

Personal presence requires personal involvement in the course of events:

Kneel down... and bow to the Lord thy God, and then His mother, and respectfully greet holy Elder Joseph. Then kiss the feet of baby Jesus lying in the manger, and ask His Mistress to give Him to you ... Take Him, hold Him, look closely at His face, kiss respectfully and rejoice in Him with faith... Just do it always with reverence and awe, for $\mathrm{He}$ is the Holiest. Return Him to His mother and watch carefully how earnestly and wisely

${ }^{11}$ Hugo de S. Victore, Eruditio didascalica, III, 11 (PL 176, 772).

${ }^{12}$ Iohannis de Caulibus, Meditationes Vitae Christi, proemium (Turnhout: Brepols, 1997). All translations of Curtusians are my own.

${ }^{13}$ Ibid. 
she takes care of Him, feeds Him and does everything that is necessary. And you, imitate her, take care of Him, if you can. Enjoy this and do not forget to meditate intently. Be Her and baby Jesus' handmaiden, as long as you can, and often look at His face, which is the desire of the angels. ${ }^{14}$

The entire treatise is full of such counsels and motifs. On the one hand, it is a technique concerning the mental attitude of the person. It is assumed that through a permanent representation and imagination, a person's mind will be prepared for complicated moral and analogical interpretations of events, either real or imagined, and the mind of the person will be more susceptible to possible religious and mystical experience. This technique may well be associated with the role theory introduced in contemporary religious studies by Hjalmar Sundén and Nils Holm: ${ }^{15}$ a person can achieve her religious goal (mystical experience), by means of participating in certain forms of role-playing. Put in another way, mystical experience is possible through a total transformation the adoption of a certain psychological mindset and of behaviour corresponding to this mindset. On the other hand, we recognize here a synesthetic perception of the meaning of the situation. Then this meaning is deployed in a meaningful comprehension of the text read. So sensual meanings are revealed in the individual religious experience. ${ }^{16}$ The application of feelings is a purposeful work of the imagination, which is carried out in the meditatio level and which involves the most precise, lucid, interiorized sensory experiences of those scenes and pictures that make up the contents of the text read.

Guigo II (d. about 1188) in 'The Ladder of Monks' (Scala Claustralium) describes meditation as an act of the mind, examining the hidden truth solely by reason. ${ }^{17}$ Meditation depends on reading, since the latter provides it with the material needed to meditate upon. In order

${ }^{14}$ Ibid., VII.

${ }^{15}$ Hjalmar Sundén, 'Saint Augustine and the Psalter in the Light of Role-Psychology', Journal for the Scientific Study of Religion, vol. 26/3 (1987), 375-82; Nils Holm, 'Sundén's Role Theory and Glossolalia', Journal for the Scientific Study of Religion, vol. 26/3 (1987), 383-89.

16 Eugene Gendlin suggested that when people think, read, speak, they feel meaning. Thus felt meaning is a sensual aspect of state of understanding, experiencing and creation of meaning. Eugene Gendlin, Experiencing and the Creation of Meaning (Evanston, Illinois: Northwestern University Press, 1997), pp. 44-5.

17 Guigo II Carthusiensis, Scala Claustralium, II; Guigues II le Chartreux, Lettre sur la Vie Contemplative (Léchelle des moines), introduction et texte critique par Edmund Colledge (OSA) et James Walsh (SJ), traduction française par 'Un Chartreux', Sources 
to describe the action of meditation, Guigo uses the metaphor of food, which was a very popular metaphor for meditation at his time: reading gives food and meditation chews it. At best, there is no meditation without reading; at worst, it becomes erroneous.

The principles of meditation that Guigo offers are designed for trained people with excellent knowledge of Scripture, who are able to build associative allegorical series of philosophical and theological concepts and biblical imagery, i.e. for the scholar. Hunger satisfied by God is the image of the III meditation in the 'Twelve meditations' (XII meditationes); it is quite physiological. The allegorical image of a sinner is a hungry man, forced to eat his excrement, and a crow and a widow of Zarephath, nursing the righteous man (3 Kings 17 [Orthodox Synod Bible]). Eating meat is an image of the rejection of transient things for Christ's sake. Eating bread is an image of a simple and humble mind, which God requires from us. A small amount of flour and oil is a symbol of the small mind that man possesses, flour is 'clear and subtle candor', a pitcher is humble thrift. Beginning with the image of starving, Guigo, through a series of biblical images, comes to the conclusion that God does not abandon those who trust in Him, and who eat a meal spiritually. The Lord nourishes the righteous men both spiritually and physically in response to their praise. This meditation is one of the simplest. In more complicated meditations Guigo offers random images, in which Abraham is identified with God the Father, Isaac with Christ, Abraham's servant with Guigo, Rebekah with the Virgin Mary, camels with sinners, and with Guigo.

Guigo's meditation technique may shock the contemporary reader. At first glance it looks like a set of rambling thoughts jumping from one topic to another. If we investigate it more closely, however, we find that certain metaphors are in the centre of associative lines. Since it is possible to understand metaphors ambiguously, the understanding mind has to build the associative lines, which clarify the meaning of the original metaphor, but also themselves are clarified by means of a deeper understanding of the original metaphor. It turns out that Guigo shows the inner work of the mind in meditation; the goal of this work is to clarify the meaning of the text read, to reveal new meanings, and to revise meanings previously clarified.

Chrétiennes, série de textes Monastiques d'Occident vol. 163/19 (Paris: Les Éditions du Cerf, 1970), pp. 80-123. 
Ludolph of Saxony (1295-1377) in Vita Christi presents another possible method of meditation. The book aims to aid readers in following God in the world. Ludolph describes events of Christ's life and encourages the reader to reflect on them. Again, he uses the method of associative lines. However they are not as arbitrary as in Guigo's 'Twelve Meditations'. The study of any chapter shows that Ludolph does not try to give a new teaching, new metaphors or unexpected allegorical interpretations of Scripture. On the contrary, his exegesis is based on the theological tradition: once Ludolph begins to interpret a passage of Scripture or clarify the Gospel for any event he describes, he gives considerable space for citing authorities (e.g., I, 91 De refectione Quattor Milium Hominum).

For instance, an expanded presentation of the text of the miracle of the seven loaves and fishes (Mt 15:32-39 and Mk 8:1-10) includes material from John Chrysostom who refers to the book of Job on human infirmities, Origen who describes these infirmities, Rabanus Maurus, and Jerome. After an extended exposition Ludolph goes directly to an anagogical interpretation, and then to the moral, where he quotes Augustine on seven virtues and seven sacraments. Further, he refers to Ambrose on the grace of God. An excerpt from John Chrysostom on the need to avoid gluttony follows. Then he cites Bernard of Clairvaux on the mystical significance of seven loaves, with references to Chrysostom and Gregory the Great. ${ }^{18}$ Thus, Ludolph bases his reflections on a careful study of the exegetical tradition. This is true for the whole book: so much Catholic and patristic material is presented throughout the 'Life of Christ' that it is indeed the guide to medieval theology.

Ludolph's interest in Christ's earthly life is associated with christology, trinitarian doctrine, and soteriology. On the one hand, this relationship makes the practice of meditation more scientific and intellectual. On the other, an inherent intellectual symbolism complicates the perception of material reality: the more relations between objects are seen, the more they are bound in spiritual knowledge that surpasses the level of material objects. The main model for Ludolph is the life of Jesus: Omnis Christi actio est nostra instructio - this principle is the right attitude toward Christ's life. Imitation of Christ is the second source and the

${ }_{18}$ Ludolphus de Saxonia, Vita Jesu Christi ex Evangelio et approbatis ab Ecclesia Catholica doctoribus sedule collecta, I, 91, ed. by L. M. Rigollot (Paris: Palmé, 1865), pp. 384-89. 
basis of correct meditation. According to Ludolph, the process of human development is through reading, imitation, and meditation. Everything starts with reading; then, to understand the meaning of Christ's actions, a person has to imitate them in her life. This repetition affects the meditation, which in turn raises reading to a new level. This scheme (lectio-meditatio-imitatio-meditatio-lectio) is repeated spirally even in the blessed condition.

Let him read the life of Christ so as to learn as much as possible to imitate

Him. After all, without imitating reading will benefit little. ${ }^{19}$

Thus, Ludolph maximally draws together lectio and meditatio through the practice of imitation (imitatio), which should be treated not as an imitation of itself, but rather as 'empathy' (Einfühlung), because one learns the holy life through understanding, awareness, imitation, delight, and joy.

Geert Grote (1340-1384) in his Tractatus de quattuor generibus meditabilium identifies four kinds of meditation. The fourth (lower) level is based on imaginative thinking which is proper to humans due to their carnal nature: it is better to denote abstract subjects by sensual images, as they will be clearer and more accessible. Thus, the imagination of the evangelical scenes is inevitable because human beings engage imagination and fantasy while reading any text. These images are necessary for the next, more profound level of reading. However, these sensual images are not only insufficient for the way to God, but also obviously dangerous, as they may prevent man's spiritual development. Geert Grote compares this fourth way of meditation with food for babies: as breast-feeding is necessary for growth, but at some point it should be abandoned, so too it is necessary to abandon the sensory images in a more mature spiritual state.

Another meaning of the imagination lies in mnemonics: with its help the scenes from the Gospel are so strongly stamped in memory that we can recall them at any time. The highest kind of meditation is thinking about the intelligible truth. Accordingly, the transition from a lower to a higher kind of meditation consists in the rejection of sensual images. Geert Grote sees the main problem of meditation in that the subject of meditation and intellectual contemplation is mediated by sensual images. That is why he raises the question: how is it possible to

${ }^{19}$ Ibid., proemium, p. 1. 
abandon the images? Geert advises to represent scenes from the Gospels as often as possible (but regularly) accompanying them by meditation. Gradually, the human soul gets used to the concepts involved in thinking, abandons sensual images, and thus gets closer to the contemplation of God. An important role in this process is assigned to the hearing of Scripture ('So then faith cometh by hearing, and hearing by the word of God', Romans 10:17), for the spoken word, though it is a sensual sign, is invisible and creates faith in people, which is not bounded to any visual images. Grote says:

But most often hearing forms in us knowledge and faith, because it forms our intellect according to genera and species, definitions and concepts of things, which requires abstraction..$^{20}$

Faith helps a person to abandon imagination and fantasy and rise to the intellectual comprehension of the particular, defined by the universal:

For faith is light, uplifting person over nature, and especially over the imagination and fantasy. ${ }^{21}$

Grote mentions only in passing the second and the third kinds of meditation. As to the second kind - mystical visions of the saints - the main thing is to distinguish the true vision (consistent with Scripture and with the previous visions of the saints, which are contained therein) from false. The third kind of meditation is on scientific propositions. They should be questioned firstly, and then only after questioning them the person may accept them.

\section{ORATIO}

Active psychological states, which are proper to reading and meditation, prepare a person to undergo spiritual experience. This experience is possible only in a passive state; prayer facilitates it. Guigo writes:

Seeing that she cannot by herself reach the desired sweetness of knowledge and experience, and seeing that the more she approaches to the depth of the heart, the more God is glorified, the soul humbles herself and flees to prayer, saying, 'Lord, invisible to anyone except the pure in heart! Here

20 Gerardus Magnus, De quattor generibus meditabilium, in Gerardo Groote, 'Il Trattato, Tractatus de quattor generibus meditabilium, introduzione, edizione, traduzione e note a cura di Ilario Tolomio (Padova: Editrice Antenore, 1975), pp. 42-118.

${ }^{21}$ Ibid. 
I am, reading and meditating, trying to find out what is true purity of heart and how to attain it, so by its means I might know You a little... I was meditating for a long time in my heart, and in my meditation a fire broke out and the desire to know You better was ignited ... not now in the rind of the letter, but in the feeling of experience ... So give to me, Lord ... a drop of heavenly rain to refresh me, thirsty, because I am burning with love. ${ }^{.22}$

The purpose of the practice of prayer is to focus the mind on one thing, the cessation of conceptual thinking.

\section{CONTEMPLATIO}

The Lord ... does not wait till she is finishing her prayer, but He breaks in at the middle. He ... is in a hurry to rescue her soul, wracked by desire ... He reinforces her, saturates, feeds, forces her to forget about the earth ... And in this higher contemplation carnal impulses are so overcome and absorbed by the soul that the flesh does not contradict the soul, and the person becomes, as it were entirely spiritual. ${ }^{23}$

Thus, prayer moves into contemplation. At this stage human consciousness completely changes, it becomes 'entirely spiritual'. The spiritual practice finds its logical conclusion here: union with God is perceived not only spiritually, but also physically.

\section{CONCLUDING REMARKS}

I focused my attention on the practice of meditation, which is justified, because it was, among the subjects I chose to investigate, the principal subject of theoretical development for medieval authors. I presented a brief interpretation of the main elements of lectio divina, which is a specifically western spiritual practice. This interpretation is certainly one of many. We have seen that the medieval understanding of spirituality is theocentric and close in proximity to theological discourse, in contrast with the modern understanding of this phenomenon, where it stands apart from the religious context and is associated rather with the moral searching of modern man. Between these two concepts is the point of contact: theology, like ethics, according to many medieval

\footnotetext{
22 Guigo II Carthusiensis, Scala Claustralium, VI.

${ }^{23}$ Ibid., VII.
} 
authors, is a practical discipline, rather than a theoretical one, which aims to introduce some of the ideals of human behaviour and to justify them. However, in general, these two interpretations of spirituality are certainly very far from each other.

The Medieval practice of lectio divina provides individuals with an ideal of behaviour only at the first, lower stages, when a person is invited to take on a role with the help of her faculties of imagination and fantasy, get used to it, and make it her own. The principle, Omnis Christi actio est nostra instructio, and the practice of 'empathy' (Einfühlung) are most important at this stage. The further practices (meditation on sensual images, and then in abstract terms on God, the Gospel events, creeds, doctrines, prayer, etc.) give a person something incomparably greater than the moral ideal - the opportunity to experience the presence of God in contemplation.

I suppose at this point we can approximate an understanding of what 'mysticism' is. Lectio divina as a spiritual practice uses sensual images (metaphors in Guigo's texts) that are destroyed at the meditatio and oratio levels. As Grote says, the aim is to transcend from sensual images and meditate using only concepts. Then, prayer destroys those concepts and, if that is done, we have a pure, clear mind. It is precisely that state of having a pure mind that we call mystical experience. I do not mean that we can identify mystics only by that state, as other psychological states (for instance, love, longing for contact with God) are necessary. However, perhaps, this state is a point where mystical experience starts. We can find the same mechanism in other religious traditions, such as Zen Buddhism and Hinduism, which supports my supposition. In Grote's interpretation of meditatio we may find the point of contact between eastern (orthodox) and western (catholic) Christian mystical traditions. Many orthodox writers and scholars have long made accusations of deep sensuality of catholic mysticism. Now we can see that they are not absolutely just, as only lower levels (which are rather means, not mystical experience itself) of lectio divina presuppose sensual images and the work of imagination. At the higher levels of that spiritual practice, however, a person must abandon all sensuality, concentrate her mind on concepts, and then make the next step to pure contemplation of God with her consciousness freed from images, concepts, or any other products of the senses and mind. 